\title{
ANALISIS PERSEPSI MATA KULIAH PUBLIC SPEAKING TERHADAP KEMAMPUAN SPEAKING, TEACHING DAN DELIVERY MAHASISWA PENDIDIKAN BAHASA INGGRIS
}

\author{
Nazriani Lubis ${ }^{1)}$ \\ Asnarni Lubis ${ }^{2)}$ \\ Universitas Muslim Nusantara (UMN) Al Washliyah \\ J1. Garu II A No. 93 Medan \\ nazrianilubis@gmail.com
}

\begin{abstract}
Abstrak
Penelitian ini bertujuan untuk menginvestigasi persepsi mata kuliah Public Speaking terhadap kemampuan public speaking, teaching, dan delivery. Untuk mencapai tujuan penenlitian, metode deskriptif kuantitatif digunakan dengan analisis presepsi mata kuliah Public Speaking terhadap kemapuan public Speaking, teaching dan delivery Mahasiswa Semester VIIA \& VIIC Pendidikan Bahasa Inggris Universitas Muslim Nusantara AlWashliyah Medan .Instrumen yang digunakan adalah angket berskala likert yang kemudian analisis data menggunakan uji regresi linear, uji $t$, uji $f$ dan uji $R^{2}$,.Berdasarkan hasil pengujian dengan menggunakan SPSS 22.00for windows dapat dilihat berdasarkan hasil penelitian, hasil perhitungan koefisen determinasi $\left(R^{2}\right)$ kelas VII A sebesar 47,2\% dan mahasiswaVII C sebesar 68.7\%.yang menunjukkan bahwa mahasiswa VIIC memiliki persepsi lebih positif. Selanjutnya, t-test VII C ditemukan bahwa nilai sig 0.018 sehingga sig $<0.05$ (0,018<0.05) yang berarti kemampuan speaking (X1) mempengaruhi persepsi mahasiswa, lalu sig 0.002 sehingga sig < 0.05 $(0,002<0.05)$ berarti kemampuan teaching(X2) mempengaruhi persepsi mahasiswa. Namun, nilai sig 0.794 sehingga sig > 0.05 (0,794> 0.05) yang berarti kemampuan delivery(X3) tidak mempengaruhi persepsi mahasiswa pada mta kuliah public speaking(Y). Lalu, hasil F-test VIIC sig 0,001<0,005 yang berarti bahwa adanya persepsi positif. Hasil penemuan ini menyimpulkan bahwa kemampuan public speaking, teaching, dan delivery mahasiswa dapat diperoleh tidak hanya dari mata kuliah Public Speaking saja.
\end{abstract}

Kata kunci: persepsi, public speaking, speaking, teaching, delivery

\begin{abstract}
This research aims to investigate students' perception of Public Speaking subject toward public speaking, teaching, and delivery skills. In order to achieve this research, VII A and VIIC English Department students of UMN Al-Washliyah were chosen as the subject of the research, then, quantitative descriptive method was used to obtain the data needed through, $t$ test, f test, and $R^{2}$ test with SPSS 22.00 for windows. Based on data analysis, $R^{2}$ test of VIIC students was higher with 68,7\% than VIIA students with $47,2 \%$ which meant VIIC students had more positive perception than VIIA student. Moreover, t-test VII C found that sig 0.018 with sig $<0.05(0,018<0.05)$ which meant speaking $(X 1)$ affect students' perception of Publlic Speaking, then, teaching $(X 2)$ with sig $<0.05(0,002<$ 0.05) meantteaching affect students' perception of public speaking subject as well. Yet, delivery (X3) was sig > 0.05 (0,794>0.05) that meant delivery was not giving a positive positive perception to the students' public speaking perception. Similarly, F test of VII C was higher than VIIA with sig 0,001<0,005. In short, VIIC students had positive perception of public speaking subject more than VIIA students had. It could be inferred
\end{abstract}


that public speaking, subjcet was not the only subject that lifted up their public speaking, teaching and delivery skills.

Keywords: perception, public speaking, speaking, teaching, delivery

\section{Pendahuluan}

\subsection{Latar Belakang}

Salah satu kemampuan yang diharapkan adalah kemampuan public speaking karena dengan memiliki kemampuan public speaking maka seseorang memililki kemampuan berkomunikasi yang baik dan secara otomatis itu dapat mendeskripsikan bahwasanya orang tersebut tidak hanya memiliki tingkat inteligensi yang sangat baik tetapi juga akan memiliki kredibilitas diri yang sangat baik pula. Mengingat betapa pentingnya kemampuan berbicara didepan umum, public speaking menjadi salah satu matakuliah wajib yang diajarkan di perguruan tinggi di Indonesia khususnya jurusan Pendidikan Bahasa Inggris dengan bobot 3 sks dengan tujuan meningkatkan keterampilan mahasiswa berbicara didepan umum dengan menggunakan metode dan tata Bahasa Inggris yang tepat. Matakuliah public speaking merupakan matakuliah lanjutan dari matakuliah speaking yang diajarkan di semester I, speaking II yang diajarkan disemester II, debate I yang diajarkan disemester III, debate II yang diajarkan disemeste IV,dan yang terakhir matakuliah public speaking diajakan disemester $\mathbf{v}$. Singkatnya, public speaking akan menjadi matakuliah terakhir yang memberikan mahasiswa kesempatan untuk bebas mengeksplor kemampuan berbicara mereka di depan umum dengan menggunakan kemampuan komunikasi. Namun, mahasiswa masih memiliki persepektif yang berbeda-beda ketika mengikuti matakuliah. Sebagaian mahasiwa memiliki persepektif yang positif dimana mereka sadar bahwa matakuliah public speaking akan sangat membantu mereka meningkatkan kemampuan public speaking dengan penggunaan Bahasa Inggris yang baik, teaching dan delivery yang baik. Sedangkan, sebagian mahasiswa memiliki presepi negative dimana mereka menganggap mata kuliah ini hanya sekedar matakuliah yang mengahapal teori-teori saja. 


\subsection{Tujuan Penelitian}

Dengan rumusan masalah diatas, maka dapat diketahui tujuan penelitian sebagai berikut:

1. Untuk mengetahui presepsi mahasiswa terhadap matakuliah public speaking terhadap kemapuan public speaking mahasiswa Program Studi Pendidikan Bahasa Inggris tahun ajaran 2016/2017.

2. Untuk mengetahui presepsi mahasiswa terhadap mata kuliah sublic speaking terhadap kemapuan teaching mahasiswa Program Studi Pendidikan Bahasa Inggris tahun ajaran 2016/2017

3. Untuk mengetahui presepsi mahasiswa terhadap matakuliah public speaking terhadap kemapuan delivery mahasiswa Program Studi Pendidikan Bahasa Inggris tahun ajaran 2016/2017

\section{Metode Penelitian}

Metode analisis data ini deskriptif kuantitatif digunakan dengan analisis presepsi matakuliah public speaking terhadap kemapuan speaking, teaching dan delivery Mahasiswa Pendidikan Bahasa Inggris Universitas Muslim Nusantara Al-Washliyah Medan.
Instrumen yang digunakan adalah angket berskala likert yang kemudian analisis data menggunakan uji regresi linear, uji t, uji f dan uji $R^{2}$.

$$
\text { Populasi yang dijadikan }
$$
dalam penelitian ini adalah seluruh mahasiswa jurusan matematika FKIP Universitas Muslim Nusantara (UMN) Al-Wasliyah semester VII, sehingga sampel diambil adalah sebagian semester VII sebanyak 2 kelas yang diambil secara random purposive, dimana Sugiyono (2010:124) menjelaskanpengambilan sampel berdasarkan pertimbangan, yang menjadi pertimbangan peneliti adalah guru dan buku ajar yang sama, maka kelas yang dipilih adalah kelas VII-A dan VII-C sebanyak 60 mahasiswa.

\section{Hasil dan Pembahasan}

Berdasarkan hasil penelitian dan pengolahan data dapat diketahui bahwa terdapat perbedaan dan persamaan hasil persepi mahasiswa VII A yang dilihat uji R sebesar47,2\% kemampuan speaking, teaching dan delivery memberikan pengaruh terhadap persepsi mata kuliah public speaking. Sedangkan nilai koefisien determinasi $\left(\mathrm{R}^{2}\right)$ 
mahasiswa VII C adalah 0,687 yang berarti kemampuan speaking, teaching dan delivery memberikan pengaruh terhadap persepsi mahasiswa sebesar $68.7 \%$. Dengan kata lain, persepsi mahasiswa VII C lebih positif terhadap mata kuliah public speaking. Secara singkat, diagram dibawah ini menunjukkan perolehan uji $\mathrm{R}^{2}$.

Gambar 1. Grafik Batang Perbandingan Besarnya Pengaruh Persepsi Mahasiswa VII A dan VII

C

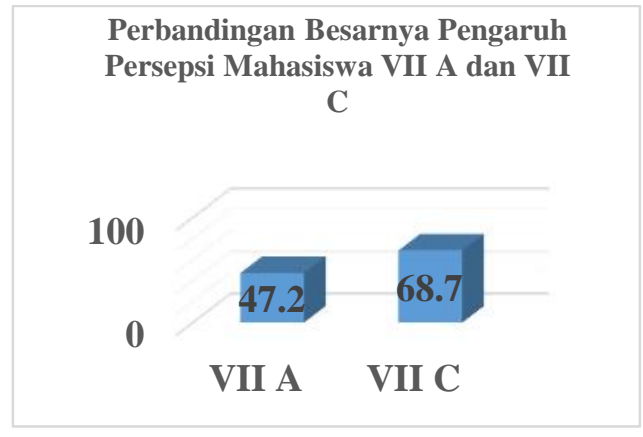

Kemudian, berdasarkan pengolaan data dengan SPSS 22.00 diketahui bahwa uji t VIIA sebagai berikut: sig 0.90 sehingga sig $>0.05$ $(0,90>0.05)$. Hal ini berarti kemampuan speaking tidak mempengaruhi persepsi mahasiswa pada mata kuliah public speaking, sebagaimana Kemudian dari nilai sig 0.484 sehingga $\operatorname{sig}>0.05(0,484>$ 0.05). Hal ini berarti kemampuan teaching tidak mempengaruhi persepsi mahasiswa pada mta kuliah public speaking. Selanjutnya, dari nilai sig 0.80 sehingga sig $>0.05$ $(0,80>0.05)$, yang juga memiliki arti bahwa kemampuan delivery tidak mempengaruhi persepsi mahasiswa pada mta kuliah public speaking.

Sedangkan, hasil uji t untuk semester VII C ditemukan bahwa nilai sig 0.018 sehingga sig $<0.05$ $(0,018<0.05)$. Hal ini berarti kemampuan speaking mempengaruhi persepsi mahasiswa pada mata kuliah public speaking. Kemudian dari nilai sig 0.002 sehingga sig $<0.05(0,002<0.05)$. Hal ini berarti kemampuan teaching mempengaruhi persepsi mahasiswa pada mata kuliah public speaking. Selanjutnya, dari nilai sig 0.794 sehingga sig > $0.05(0,794>0.05)$, yang juga memiliki arti bahwa kemampuan delivery tidak mempengaruhi persepsi mahasiswa pada mta kuliah public speaking. Dengan demikian berdasarkan kriterian pengujian hipotesis secara parsial dapat disimpulkan bahwa variabel kemampuan speaking dan teaching mempengaruhi persepsi mahasiswa VII C pada mata kuliah public speaking. Tetapi variabel 
kemampuan delivery tidak mempengaruhi persepsi mahasiswa VII C pada mata kuliah public speaking.

Selanjutnya, hasil uji F VII A menunjukkan bahwa nilai Sig sebesar $0.001(0,001<0,05)$. Dengan demikian dapat disimpulkan bahwa ada pengaruh yang positif dan signifikan secara simultan kemampuan speaking, taeching dan delivery terhadap persepsi mahasiswa VII A terhadap mata kuliah public speaking. Namun, untuk hasil uji F mahasiswa semester VII C menunjukkan nilai Sig sebesar $0.001(0,001<0,05)$. Dengan demikian dapat disimpulkan bahwa ada pengaruh yang positif dan signifikan secara simultan kemampuan speaking, teaching dan delivery terhadap persepsi mahasiswa VII C terhadap mata kuliah public speaking.

Secara keseluruhan, hal ini menunjukkan bahwa kemampuan speaking mahasiswa dapat ditingkatkan bukan hanya melalui mata kuliah public speaking saja, karena beberapa alasan; pertama, karena mata kuliah public speaking merupakan mata kuliah yang

menggabung teori dan praktis secara bersamaan, yang mana ini menuntut mahasiswa untuk mampu memahami teori-teori public speaking dan mempratekkannya dengan durasi yang begitu singkat dalam setiap pertemuannya, dan alasan kedua adalah masih ada beberapa mata kuliah yang bersifat pratikal meningkatkan kemampuan berbicara Bahasa Inggris mahasiswa, seperti; speaking dan debate. Selain itu, untuk kemampuan teaching juga dapat ditingkatkan melalui mata kuliah micro teaching yang 100\% melatih kemampuan teaching mahasiswa. mata kuliah public speaking hanya memberikan kesempata mahasiswa untuk meningkatkan kemampuan mereka menorganize dan menyajikan suatu materi termasuk materi mengajar. Sedangkan, kemampuan delivery tidak hanya dapat diperoleh dari mata kuliah public speaking karena mahasiswa menganggap komunikasi non-verbal dapat ditingkatkan dengan frekuensi presentase di dalam kelas pada mata kuliah apapun.

Dengan kata lain, kemampuan speaking dan teaching mahasiswa VII C memiliki pengaruh 
terhadap persepsi mahasiswa terhadap mata kuliah public speaking. Sehingga mahasiswa menganggap bahwa dengan adanya mata kuliah public speaking bukan hanya dapat meningktakan kemampuan mereka berbicara menggunakan Bahasa Inggris yang benar dan dengan akurasi tata bahasa yang tepat, tetapi juga dapat meningkatkan kemampuan teaching mereka karena dengan mata kuliah public speaking memberikan kesempatan kepada mahasiwa untuk mampu mengorganize sebuah materi dan menyajikan dengan struktur yang benar, termasuklah pada hal ini materi mengajar, selain itu juga memberikan kesempatan kepada mahasiswa untuk mampu berkomunikasi dan berinteraksi secara efektif dengan lawan bicara termasuk kepada murid di dalam kelas pada saat proses pembelajaran berlangsung.

Secara singkat, baik mahasiswa VII A dan VII C menganggap bahwa mata kuliah public speaking memberikan dampak yang positif terhadap terhadap kemampuan speaking, teaching dan delivery. Tetapi, mahasiswa VII C memiliki persepsi yang lebih posotif terhadap kemampuan kemampuan speaking, teaching dan delivery.

\section{Kesimpulan}

Berdasarkan hasul dan pembahasan penelitian, maka dapat disimpulkan bahwa;

1. Mahasiswa VII C memiliki persepi yang positif mata kuliah public speaking terhadap kemampuan speaking mahasiswa dimana mahasiswa menganggap mereka memiliki kemampuan speaking yang jauh lebih baik setelah mengikuti mata kuliah public speaking. Sedangkan mahasiswa VII A tidak memiliki persepsi yang positif hal ini dikarenakan mahasiswa menganggap mata kuliah public speaking merupakan gabungan antara teori dan praktek yang dilakukan secara bersamaan, sehingga mereka lebih memiliki pemahaman/pengetahuan tentang public speaking secara teoritis saja

2. Mahasiswa VII C memiliki persepi yang positif mata kuliah public speaking terhadap kemampuan teaching mahasiswa dikarenkan mahasiswa memiliki kemampuan mengorganize, menyajikan materi termasuk matei mengajar, selain itu 
mahasiswa juga memiliki kemampuan berkomunikasi secara efektif termasuk kepada siswa ketika merek mengajar pada saat PPL/KKN. Sedangkan mahasiswa VII A tidak memiliki persepsi yang positif terhadap mata kuliah public speaking dalam meningkatkan kemampuan teaching mereka karena mereka menganggap bahwa kemampuan teaching dapat diperoleh pada mata kuliah khusus, yaitu; micro teaching.

3. Baik mahasiswa VII A da VII C tidak memiliki persepsi yang positif terhadap kemampuan delivery. Mereka menganggap bahwa kemampuan delivery dapat ditingkatkan melalui frekuensi presentase di dalam kelas.

\section{Daftar Pustaka}

Arslan, Akbarov. 2012.EFL Learners Perception and Attitude Towards ESP. Jurnal Aeta Didaetiea Napogensia. Volume 5 No14. Hal:1-5

Bogdan,R \& Biklen, S. 1982. Qualitative Research for Education (2 $2^{\text {nd }}$ Ed). Boston: Allan and Baeon.

Centra, Gaubatz. 2005. Students' Perception of Learning and Instructional Effectiveness in Colloge Course. Artikel Penelitian. Avalidity of SIRII
Ghozali., 2013. Aplikasi Analisis Multi variate Dengan Program SPSSIB M21 Edisi 7. Badan Penerbit Universitas Diponegoro.

Iberri, Shea. 2009. Using Public Speaking Tasksin English Language Teaching English Language Teaehing Forum. Number 2

Lucas,EStephen.2009.TheArtofPubli cSpeaking10thEdition.MeGrawHi 11.NewYork.

LuhPut, Artini. 2013. Penggunaan Englishas Mediumof Instruction (EMI) dan Konsekuensinya Terhadap Proses Pembelajaran Ditinjau Dari Perspesi Siswa. Jurnal Ilmu Sosial dan Humaniora. Volume 2 No. 1

Maesaroh, Siti. 2014. Urgensi Public Speaking Terhadap Kinerja Guru. Skripsi. Fakultas Tarbiyah dan Keguruan. UIN Syarif Hidayatullah. Jakarta.

Mardiana, dkk.(2013). Studi Tentang Persepsi Siswa Pada Layanan Bimbingan dan Konseling di SMK Kecamatan Sukomanunggal Surabaya. Jurnal BK UNESA. Volume 2 Nomor 1..72.80

Zitouni, Nadia. 2013. The Useof Sudents's Oral Presentation in Enhancing Speaking Skill in Teaching Language Speaking Skill in Study of Second Year Studentsat The Department of English in Bizka University. Thesis. 
Jurnal Penelitian Pendidikan Bahasa dan Sastra Vol. 2 No. 2. Oktober 2017 